\title{
Effect of Fly Ash and Cement on the Engineering Characteristic of Stabilized Subgrade Soil: An Experimental Study
}

\author{
Partab Rai $\mathbb{D}^{1},{ }^{1}$ Wenge Qiu ${ }^{D},{ }^{1}$ Huafu Pei $\mathbb{D}^{2},{ }^{2}$ Jihui Chen, ${ }^{1}$ Xufeng Ai, ${ }^{1}$ Yang Liu, ${ }^{1}$ \\ and Mahmood Ahmad (iD ${ }^{3}$ \\ ${ }^{1}$ Key Laboratory of Transportation Tunnel Engineering, Ministry of Education, School of Civil Engineering, \\ Southwest Jiaotong University, Chengdu 610031, China \\ ${ }^{2}$ State Key Lab of Coastal and Offshore Engineering, Dalian University of Technology, Dalian 116024, China \\ ${ }^{3}$ Department of Civil Engineering, University of Engineering and Technology Peshawar (Bannu Campus), Bannu 28100, Pakistan
}

Correspondence should be addressed to Wenge Qiu; qiuwen_qw@163.com

Received 9 May 2021; Accepted 7 August 2021; Published 20 September 2021

Academic Editor: Yong-Zheng Wu

Copyright (c) 2021 Partab Rai et al. This is an open access article distributed under the Creative Commons Attribution License, which permits unrestricted use, distribution, and reproduction in any medium, provided the original work is properly cited.

The effectiveness of the use of waste fly ash (FA) and cement (OPC) in the stabilization of subgrade soils and the reasons likely to influence the degree of stabilization were investigated. Incorporating waste fly ash (FA) and cement (OPC) as additives leads to significant environmental and economic contributions to soil stabilization. This study involves laboratory tests to obtain the Atterberg limit, free swell index (FSI), the unconfined compressive strength (UCS), the California bearing ratio (CBR), and the scanning electron microscope (SEM). The test results for the subgrade soil illustrate that the Atterberg limit, plasticity index, and free swell index are decreasing with the addition of different proportions of fly ash and cement, i.e., $0 \%, 5 \%, 10 \%, 15 \%$, and $20 \%$ and $0 \%, 2 \%, 4 \%, 6 \%$, and $8 \%$, respectively. The CBR value of untreated soil is $2.91 \%$, while the best CBR value of fly ash and cement mixture treated soil is $10.12 \%$ (20\% FA+8\% OPC), which increases $71.34 \%$ from the initial value. The UCS of untreated soil is $86.88 \mathrm{kPa}$ and treated soil with fly ash and cement attains a maximum value of $167.75 \mathrm{kPa}(20 \% \mathrm{FA}+8 \%$ OPC), i.e., increases by $48.20 \%$ from the initial value. The tests result show that the stability of a subgrade soil can be improved by adding fly ash and cement. While effectiveness and usability of waste FA and cement are cost-effective and environmentally friendly alternatives to expansive soil for pavement and any other foundation work in the future.

\section{Introduction}

Emerging tendency of utilizing waste material in soil strengthening or soil stabilization is operational all over the world in present times. The primary reason behind this trend is the enormous production of fly ash, plastics, rice husk, and other wastes, which are not merely harmful but also leads to deposition problems. Using these wastes in construction work will tremendously reduce this problem. For example, soil stabilization is a technology designed to increase or maintain soil stability and chemical changes to improve its engineering properties [1-4]. More than 500 years ago, the concept of stabilization was pioneered [2,5]. In ancient Egypt, Greece, and Rome, treated earth roads were used in soil lime mixtures [5,6]. Stabilization can deal with all kinds of subgrade materials, from expansive clay to granular sub- stances. This allows the establishment of design precedents and the determination of suitable chemical additives and admixture rates to achieve the required engineering performance. At the beginning of the 20th century, around the 1930s, road construction in Europe was paved with stabilized soil [7]. The advantages of the stabilization process include higher resistance values, reduced plasticity, reduced permeability, and reduced thickness of the pavement and a reduction of transport or handling of excavated materials. Stabilization of subgrade soils with mixtures controls possible changes in soil volume and improves soil strength [8].

The soil generally is weak and has not enough stability in heavy loading. This paper is aimed at examining on stabilization of the soil using fly ash activated by cement. Several reinforcement methods can be used to stabilize subgrade materials. These methods include chemical additive 
stabilization, soil replacement, compaction control, rewetting, humidity, surcharge, and thermal processes [9]. These techniques may have the disadvantage of inadequate performance and high costs. Based on the literature, fly ash and cement are low-cost and effective for soil stabilization [9, 10]. Generally, a pavement is a relatively stable shell built on natural soil to support and distribute a wheel load and provide a good wearing course [11]. These pavements are destroyed at a shorter time due to variations in soil properties and regular application of wheel loads, which can lead to an unsustainable settlement. Further variation in moisture, freeze action, rise, or decrease in the water content of the clay soil leads to further disintegration of the pavement, which leads to a higher cost repair operation [11]. In addition, the use of stabilizing agents in the road and subgrade work with weak soil conditions strengthens other characteristics, such as cohesion, and helps to improve structures or embankments. Eventually, this will lead to a significant decrease in the cost of road maintenance $[4,11]$. The stabilization of different admixtures can improve the strength of the soil. Our aim is to work on fly ash and cement as admixtures.

Fly ash is the coal residue of the thermal power plant, which is regarded as a problematic solid waste in the world. The conventional FA treatment technology leads to degradation and pollution of cultivated land $[12,13]$. FA consists of an amorphous ferroalumino silicate with a matrix very similar to the soil. The elemental composition of the FA (toxic elements) differs with the type and source of the coal used [14-16]. It is estimated that the annual output of coal ash in the world is about 600 million tons, of which fly ash accounts for about $75-80 \%$ of total ash, about 500 million tons $[17,18]$. Fly ash can be treated as the fifth largest raw material reserve in the world [19]. As a result, the volume of coal waste (fly ash) generated by industries and thermal power plants is rising worldwide. The disposal of significant amounts of fly ash has become a primary environmental concern [17]. The inclusion of FA to soil can enhance the physicochemical properties as well as soil nutritional character, and the degree of modification depends on soil, and FA properties [16]. An estimated 6,898 MW to generate 5.2 million tons of fly ash per year in Pakistan. Because of the high costs of disposal and environmental protection, the use of FA in the construction and agriculture sector may be a feasible choice [20]. In Pakistan, the ongoing Diamer Basha Dam and the $21 \mathrm{MW}$ Tangir Hydropower Project will use concrete from Ordinary Portland Cement combined with fly ash and other additives [21, 22]. The Frontier Engineering Organisation said, "This reduces thermal loads on the dam and reduces chances of thermal cracking," according to China Daily News. China-supported projects are scheduled to be completed in 2028 [21]. Besides, the engineering properties of expansive soils such as compaction, strength, hydraulic conductivity, swell potential, free swell index (FSI), and plasticity were determined precisely at $0,5,10$ 15 , and 20 percent respectively, in order to investigate the effectiveness of fly ash. Decreased plasticity facet, hydraulic conductivity, and FSI were discerned from the findings due to the rise in the overall maximum dry unit weight [23].
However, cement remains the oldest binding agent since the advent of soil stabilization technology in the 1960s. It can be considered an important stabilizer or hydraulic binder because it can be used on its own to achieve the desired stabilizing effect $[24,25]$. Cement reaction is independent of soil minerals, and the primary function is to react to water that may be present in some soil. Almost cement stabilization decreases cohesiveness (plasticity), volume expansion, or compressibility and increases strength. Meanwhile, compared with lime and cement, fly ash has little cementitious property. Therefore, in the presence of a small amount of activator, a chemical reaction may occur to form cementitious compounds, which help improve the strength of subgrade soil [24, 26]. Moreover, many researchers [5, 27-32] have conducted a lot of research on the strength of lime, fly ash and cement, cement, lime fly ash, marble powder, lime rice husk, and their applicability as road and subbase. Since then, many efforts have been made around the world to confirm the treatment mechanism of expansive subgrade soil in highway fields to carry out appropriate pavement design and construction [33-35].

The main contribution of this paper focuses on the influence of fly ash and cement on the stabilization of subgrade soil. Besides, to make the stabilization work more economical than before, and to make use of vast waste raw material fly ash very important, the characteristics investigated in this study include the Atterberg limits, free swell index, optimum moisture content (OMC), maximum dry density (MDD), UCS, CBR, and SEM analysis. Through the experiments in the laboratory, different results are obtained from the tests. These results infer that the strength parameter increases and the Atterberg limit decrease. Finally, their contributions to subgrade soil stabilization are discussed, and the possible uses of stabilization materials are proposed. The structure of the paper is as follows. In Section 2 presents the raw materials, methods, and experimental laboratory processes. In Section 3, results and discussions are given. In Section 4, their comprehensive performance is evaluated, and the concluding remarks are made.

\section{Materials and Methods}

The primary materials used in this study are soil, fly ash, and Portland cement. This section describes the properties of these materials.

2.1. Soil. In this investigation, subgrade soil samples were collected from the Toll Plaza National Highway in Hyderabad, Pakistan, were obtained from a depth of 0.5 to $1 \mathrm{~m}$ from ground level, and had just $5.28 \%$ moisture content, which is insignificant in consideration. As per the norm, the soil is classified as A-2-4. This subgrade soil is grey in color. Geographic coordinates, $25^{\circ} 22^{\prime} 12.40^{\prime \prime} \mathrm{N}$ latitude, $68^{\circ} 13^{\prime} 1.32^{\prime \prime} \mathrm{E}$ longitude as shown in Figure 1. Besides, according to the specifications, a large number of tests were carried out to determine the engineering properties of soil samples. The results are demonstrated in Section 3. 

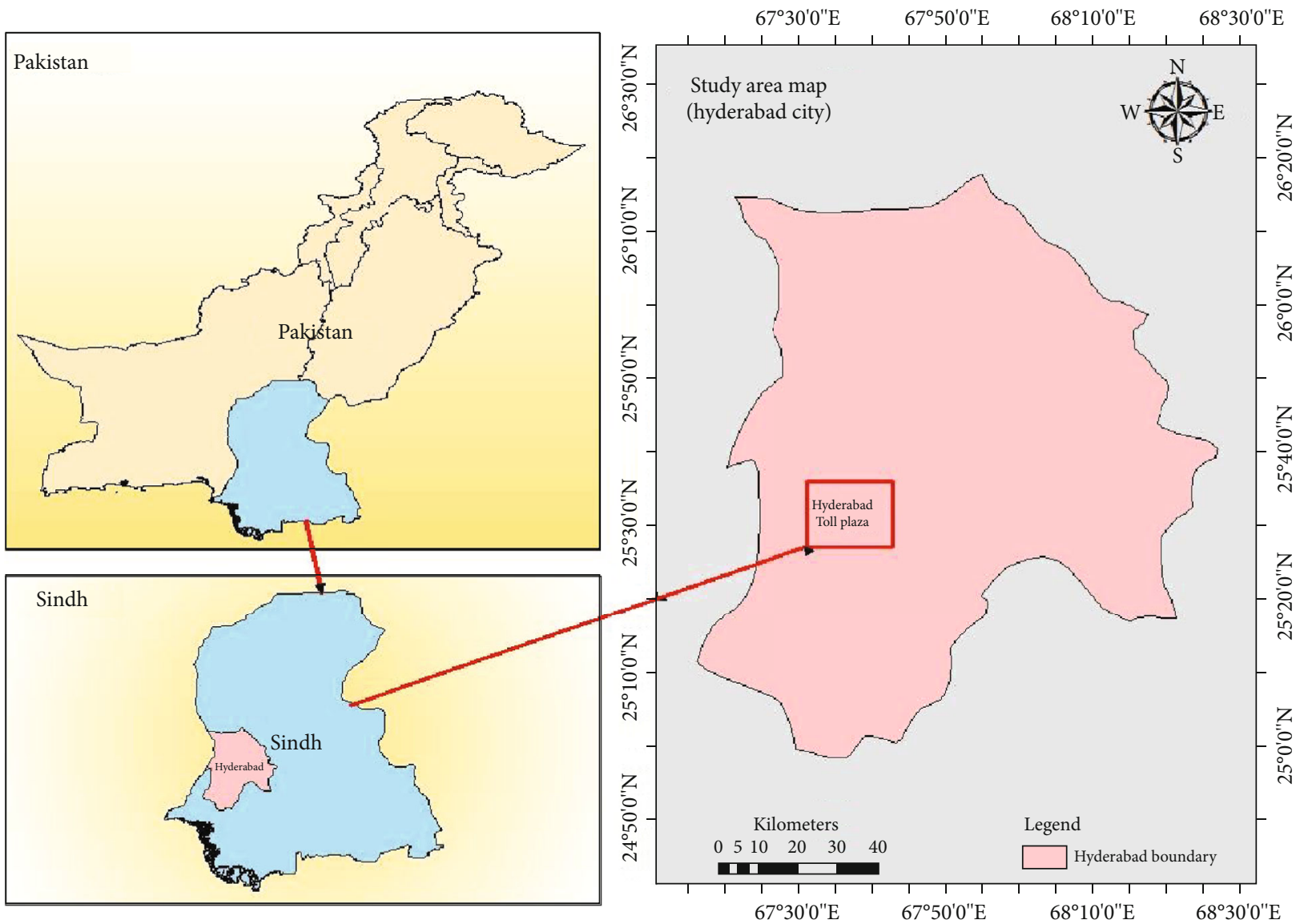

FIgURE 1: The geographical location of the test site.

2.2. Fly Ash. Class-F fly ash is taken from Jamshoro, Sindh, Pakistan. It was air-dried and pulverized. Fly ash is a waste (by-product) of the Jamshoro coal power plant. Fly ash by itself has tiny cementitious properties compared to cement and lime. Therefore, in the presence of a small amount of activator, a chemical reaction can occur to form cementitious materials conducive to improving the strength and performance of subgrade soil. The chemical composition of fly ash is illustrated in Table 1.

2.3. Cement. Ordinary Portland cement generally used for this study is from the locally available cement market. The essential components of OPC are shown in Table 1.

2.4. Methodology. Fly ash and cement additives are used as admixtures to blend with the subgrade soil for stabilization. In this study, different proportions of fly ash and cement should be tried until the desired strength is achieved. A reasonable guideline is, to begin with, to use 5\% fly ash and 2\% cement. Then, appropriate percent increments are added for various trials. In the initial trial, the proportion of activator (cement content) applied to each should be one part of cement and two parts of fly ash, but it can be different according to experience and literature review $[6,23,35$, 36]. After performing some dummy tests, we moved on towards our original sample. It looked tedious in starting because of inadequate techniques in experimental work,
TABLE 1: The chemical components of fly ash and OPC.

\begin{tabular}{lcc}
\hline Components & Class F fly ash & OPC \\
\hline $\mathrm{SiO}_{2}$ & 55.2 & 61 \\
$\mathrm{Al}_{2} \mathrm{O}_{3}$ & 26.8 & 20.5 \\
$\mathrm{Fe}_{2} \mathrm{O}_{3}$ & 12 & 4 \\
$\mathrm{CaO}$ & 2 & 10.5 \\
$\mathrm{MgO}$ & 2.5 & 2 \\
$\mathrm{SO}_{3}$ & 1.5 & 2 \\
Fineness $\left(\mathrm{cm}^{2} / \mathrm{g}\right)$ & - & 3110 \\
Ignition loss $(\%)$ & - & 2.2 \\
\hline
\end{tabular}

but dummy tests helped us understand the procedures of all tests. The methodology used for this research work was to divide samples into two parts: the soils at the natural stage and the second with fly ash and cement mixes. Initial soil tests were performed on samples Figure 2. After which, they were mixed mechanically (physical mixing) with fly ashcement. The fly ash and cement used for this study were collected from the location in Hyderabad. At the rate of $0 \%, 5 \%$, $10 \%, 15 \%$, and $20 \%$ fly ash and $0 \%, 2 \%, 4 \%, 6 \%$, and $8 \%$ cement by weight. After mixing with mentioned proportion, tests were performed as shown in Figure 2. Finally, 


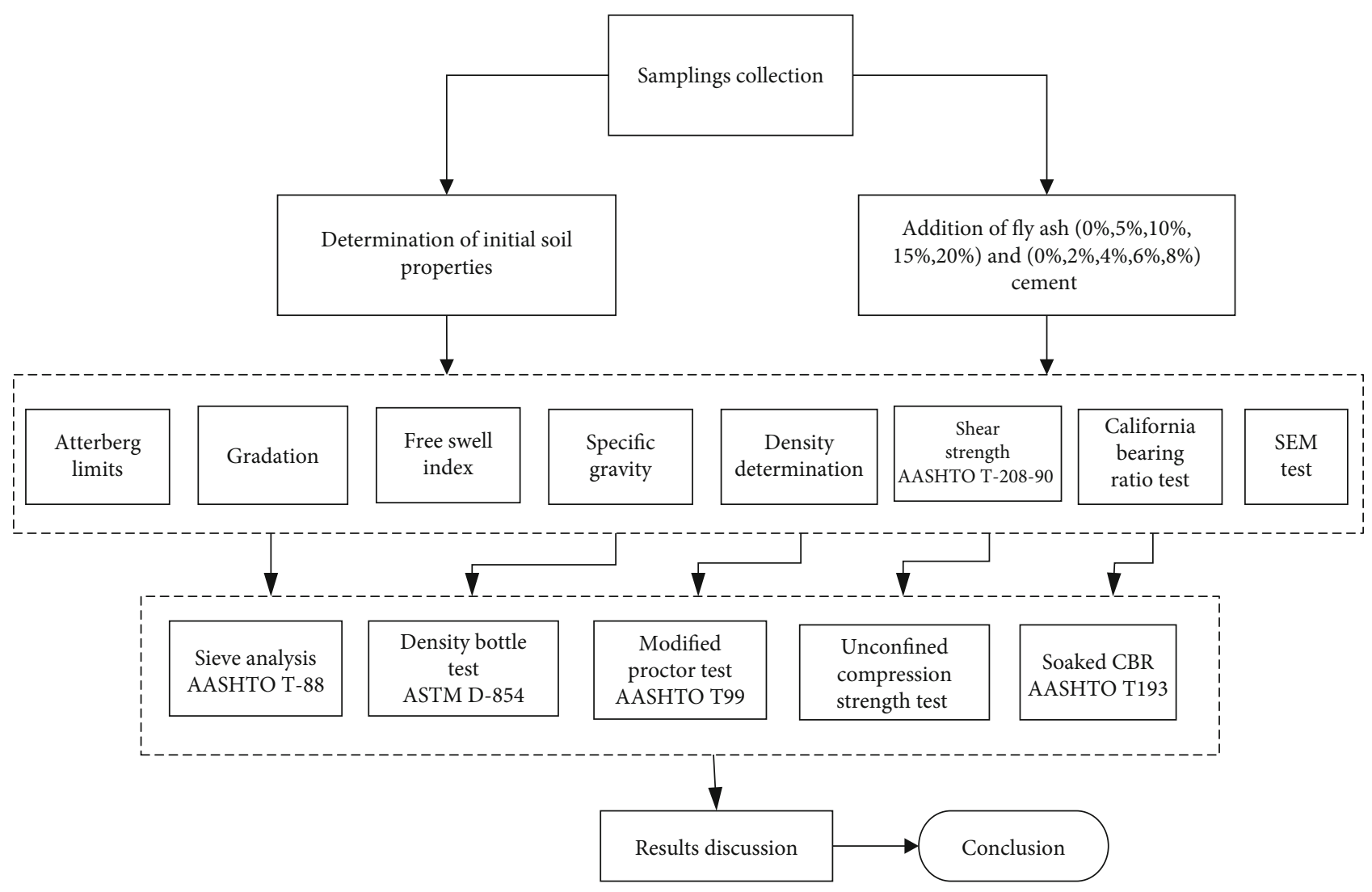

FIgURE 2: Subgrade soil tests with and without additives.

TABle 2: Properties of subgrade soil.

\begin{tabular}{lc}
\hline Properties & Obtained value \\
\hline Moisture content (\%) & 5.28 \\
Liquid limit (\%) & 27.5 \\
Plastic limit (\%) & 17.5 \\
Plasticity index (\%) & 10 \\
pH & 4.03 \\
Specific gravity & 2.72 \\
Silt (\%) & 70.49 \\
Clay (\%) & 13.76 \\
Sand (\%) & 15.78 \\
Free swell index $(\%)$ & 0.410 \\
Dry density (g/cm ${ }^{3}$ ) & 2.13 \\
UCS (kPa) & 86.88 \\
California bearing ratio & $2.91 \%$ \\
\hline
\end{tabular}

comparisons were drawn between soil at a natural state and soil mixed with said proportion.

\subsection{Laboratory Experiments Conducted}

2.5.1. Liquid Limit (as per AASHTO T-90). Liquid limit is perceived as water content. The precise number 25 blow was given in the standard LL apparatus, which uses a speci-
TABLE 3: Atterberg limits in subgrade soil by adding fly ash and cement.

\begin{tabular}{lccc}
\hline Mix ratio & PL & LL & Plasticity index \\
\hline Soil+0\% FA+0\% OPC & 19.5 & 29.51 & 10.0 \\
Soil+5\% FA+2\% OPC & 23.905 & 34.78 & 10.87 \\
Soil+10\% FA+4\% OPC & 22.58 & 31.71 & 9.13 \\
Soil+15\% FA+6\% OPC & 18.98 & 28.67 & 9.72 \\
\hline
\end{tabular}

fied number of slotting tools to close standard size grooves on the specimen. The flow curve is represented on a semilogarithmic plot on a logarithmic scale. The water content equal to 25 strokes is decoded from the curve and calibrated to the nearest integer as the soil's liquid limit.

2.5.2. Plastic Limit (as per AASHTO T-91). PL in the finegrained soil is the water content at which the soil rolled into threads with the smallest diameter of $3 \mathrm{~mm}$, which is expressed as a whole amount extracted from the mean of the PL moisture content.

2.5.3. Modified Proctor Test (as per AASHTO T99). A modified Proctor compaction test is used to evaluate the maximum dry density and optimal moisture content of subgrade soil. 


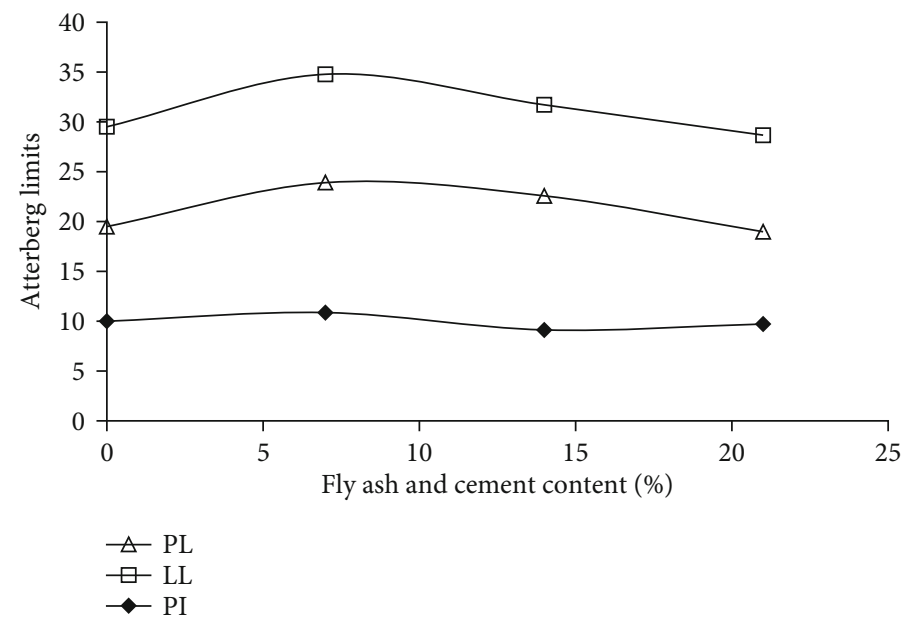

Figure 3: Effect of fly ash and cement on PL, LL, and PI.

2.5.4. Free Swell Index (according to IS-2720). The free swelling index is defined as an increase in volume caused by external impediments when soil is submerged in water.

2.5.5. CBR Test (as per AASHTO T-193). CBR is the proportion of the force required per unit area to penetrate the soil with a standard circular piston at a speed of $1.25 \mathrm{~mm} / \mathrm{min}$ to the corresponding force needed to penetrate the standard substance. Normally, the penetration between 2.5 and 5 millimeter is considered separately, with the ratio at $5 \mathrm{~mm}$ being more outrageous than at $2.5 \mathrm{~mm}$, and the ratio at $5 \mathrm{~mm}$ is used.

2.5.6. UCS Test (as per AASHTO T-208-90). UCS $\left(q_{u}\right)$ is the load needed per unit area on which a cylindrical sample of a cohesive soil falls in compression.

$$
q_{u}=\frac{P}{A}
$$

\section{Results and Discussion}

Laboratory experiments were carried out on natural soil samples to evaluate various properties. The test results are illustrated in Table 2.

As shown in Table 2, the primary index properties of expensive subgrade soil without admixtures are demonstrated. The schematic description of these comparisons with admixtures is discussed separately in coming subsections.

3.1. Influence of Fly Ash and Cement on the Engineering Properties of Subgrade Soil. Laboratory experiments were carried out, and the Atterberg limits were found, through which we were able to obtain the liquid limit (LL) and the plastic limit (PL). Through these two limits, we finally get the plasticity index (PI). Fly ash and cement with subgrade soil were extensively examined with the various percentages specified in earlier Section 2, and the results are shown in Table 3.
TABLE 4: Effects by fly ash and cement on the FSI value.

\begin{tabular}{lccc}
\hline $\begin{array}{l}\text { Mix } \\
\text { proportion }\end{array}$ & $\begin{array}{c}\text { Free swell } \\
\text { index (\%) }\end{array}$ & $\begin{array}{c}\text { Degree of } \\
\text { expansiveness }\end{array}$ & $\begin{array}{c}\text { Percentage } \\
\text { decrease (\%) }\end{array}$ \\
\hline $\begin{array}{l}\text { 0\% FA+0\% } \\
\text { OPC }\end{array}$ & 41 & High & - \\
$\begin{array}{l}5 \% \text { FA+2\% } \\
\text { OPC }\end{array}$ & 34.3 & Moderate & 16.34 \\
$\begin{array}{l}10 \% \text { FA+4\% } \\
\text { OPC }\end{array}$ & 26.4 & Moderate & 35.60 \\
$\begin{array}{l}15 \% \text { FA+6\% } \\
\text { OPC }\end{array}$ & 20.6 & Moderate & 49.75 \\
$20 \%$ FA+8\% & 12 & Low & 70.73 \\
OPC & & & \\
\hline
\end{tabular}

Table 3 reveals that with the expansion of fly ash and cement as the supplement of subgrade soil, the plastic limit and the liquid limit of the mixture first increase then decrease, thus paving the road for brittle and stiffer soil. Figure 3 illustrates the variations of LL and PL. It can be seen from the previous results that the increase and decrease of plastic limit value will eventually lead to the decline in the plastic index. The plasticity index value is further reduced by adding fly ash and cement to the subgrade soil, indicating compressibility.

3.2. Influence of Fly Ash and Cement on Free Swell Index (FSI). The change of free expansion index of different percentages of subgrade soil, fly ash, and cement mixture is shown in the table. Therefore, we can say that the addition of fly ash and cement reduces the FSI value, which implies a decrease in the degree of the expansiveness of the blended mixture. The results are presented in Table 4 and Figure 4.

The free soil index is expressed as follows [37]:

$$
\operatorname{FSI}(\%)=\left(\frac{V_{w}-V_{k}}{V_{k}}\right) \times 100 \text {, }
$$

where $V_{w}$ and $V_{k}$ are the volume of soil sample read 


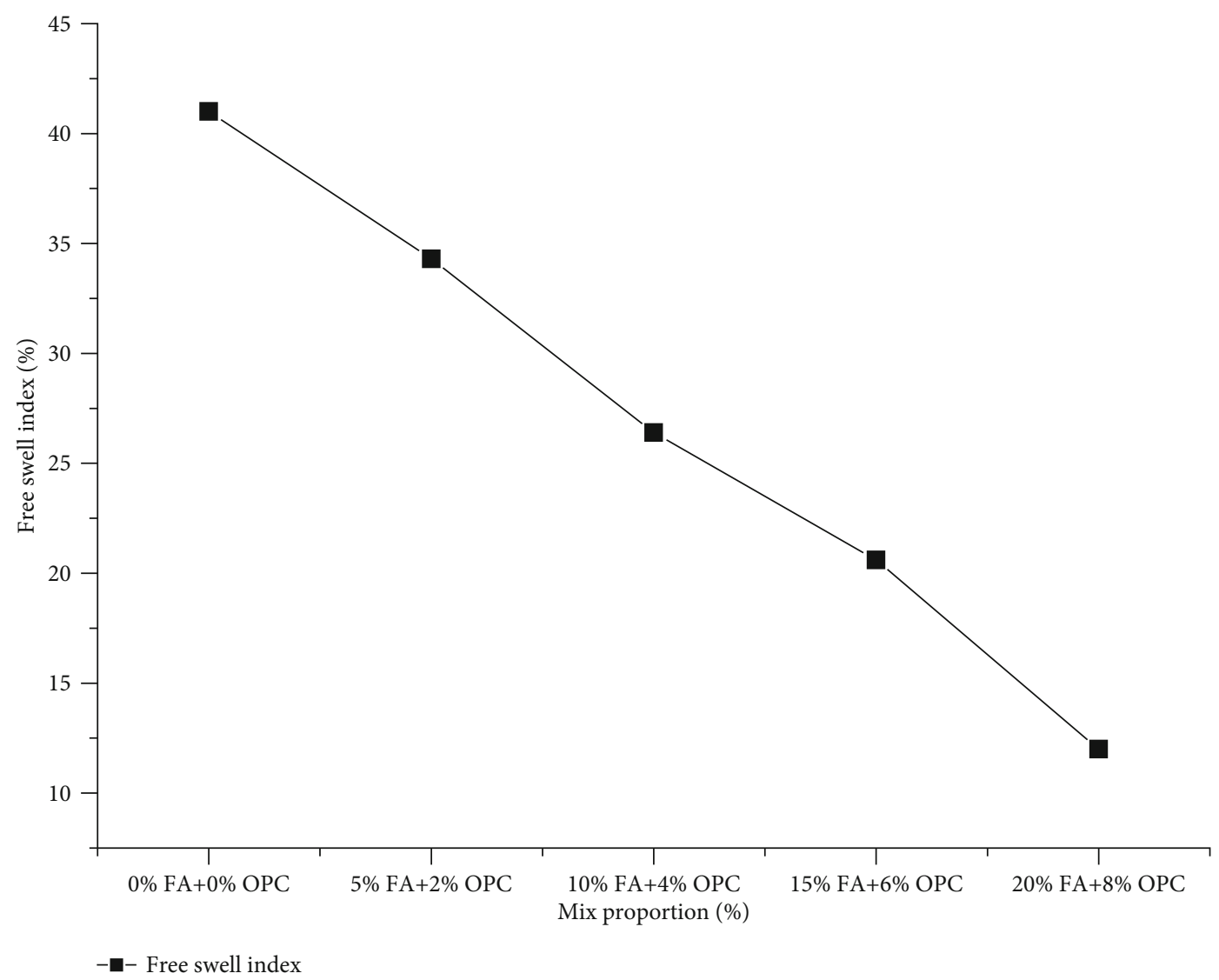

FIgURE 4: Free swell index for fly ash and cement mixes.

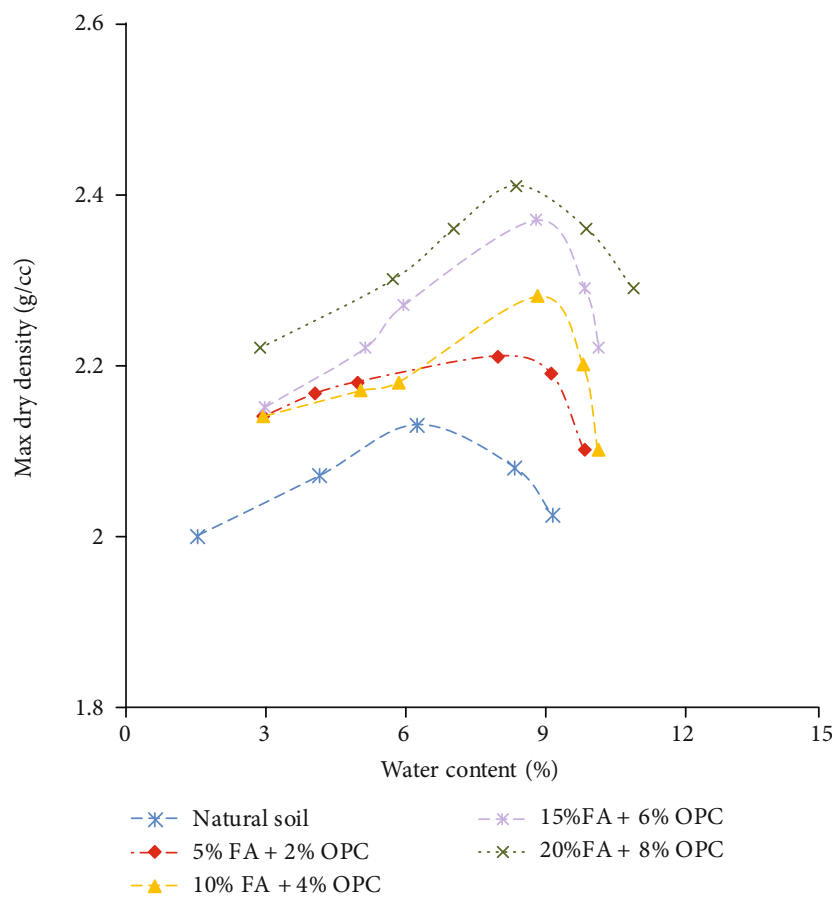

FIGURE 5: Maximum dry density vs. optimum moisture content for cement and fly ash mixes.
TABLE 5: The compaction test results.

\begin{tabular}{lcc}
\hline Mix ratio & $\begin{array}{c}\text { Moisture content } \\
(\%)\end{array}$ & $\begin{array}{c}\text { Maximum dry density (g/ } \\
\text { cc) }\end{array}$ \\
\hline $\begin{array}{l}\text { 0\% FA+0\% } \\
\text { OPC }\end{array}$ & 6.31 & 2.13 \\
$5 \%$ FA+2\% & 8.05 & 2.21 \\
OPC & \\
$10 \%$ FA+4\% & 8.94 & 2.28 \\
OPC & \\
$\begin{array}{l}15 \% \text { FA+6\% } \\
\text { OPC } \\
20 \% \text { FA+8\% }\end{array}$ & 8.89 & 2.37 \\
OPC & 8.46 & \\
\hline
\end{tabular}

from a graduated cylinder filled with distilled water and kerosene, respectively.

3.3. Influence of Fly Ash and Cement on Compaction Values. Compaction is a method of increasing soil density by using mechanical tools to remove air voids and liquids between soil particles. Standard proctor compaction tests are conducted in the laboratory to determine the optimum moisture content (OMC) of the soil at maximum dry density (MDD). The results are illustrated in Figure 5 and Table 5. 


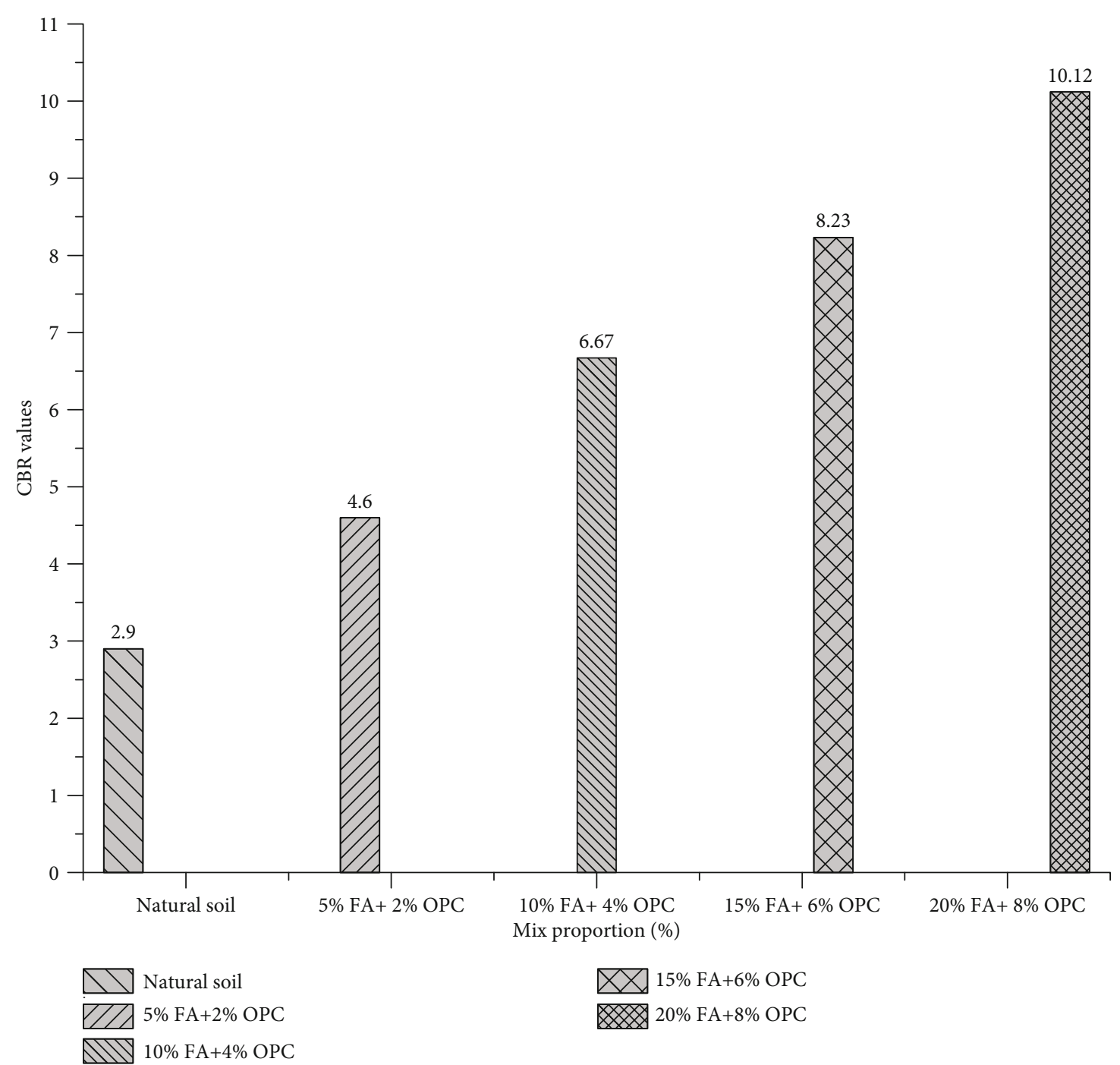

Figure 6: California bearing ratio of fly ash and cement mixture.

TABLE 6: The effect of adding cement and fly ash on the UCS value.

\begin{tabular}{lccc}
\hline Mix proportion & $\begin{array}{c}\text { 1-day UCS } \\
(\mathrm{kPa})\end{array}$ & $\begin{array}{c}7 \text {-day UCS } \\
(\mathrm{kPa})\end{array}$ & $\begin{array}{c}14 \text {-day UCS } \\
(\mathrm{kPa})\end{array}$ \\
\hline $\begin{array}{l}\text { Natural soil } \\
5 \% \text { FA+2\% }\end{array}$ & 86.880 & - & - \\
OPC & 95.314 & 113.86 & 123.683 \\
$10 \%$ FA+4\% & 105.48 & 114.85 & 133.80 \\
OPC & 120.58 & 136.42 & 151.515 \\
$15 \%$ FA+6\% & & & \\
OPC & 124.47 & 146.11 & 167.75 \\
$\begin{array}{l}\text { OP FA+8 } \% \\
\text { OPC }\end{array}$ & & & \\
\hline
\end{tabular}

Variance in dry density values is shown in Figure 5. It is inferred that the water content disturbs the density of the soil. As the percentage of water increases, the compacted density tends to decrease until the max dry density is reached, limiting the further inclusion of water to decrease the density. In adding fly ash and cement, the water content increases slightly, which naturally reduces the optimal water content and increases the MDD. Thereof, we can conclude that their maximum dry density is 2.41 in addition to $20 \%$ FA and $8 \%$ cement $(8.46 \%$ water $)$.

3.4. Effect of Fly Ash and Cement on California Bearing Ratio. The California bearing ratio (CBR) tests were conducted per the AASHTO code. The mold was a standard CBR with a detachable collar. The test was conducted on samples prepared at the modified Proctor's optimum water content and maximum dry density. Before the test, the soil additive mixture was compacted under the optimum water content and soaked in water for 4 days under the condition of overload weight of $5.72 \mathrm{~kg}$. The results are plotted in Figure 6.

Figure 6 reveals that the CBR value of the initial subgrade soil is 2.9. With the inclusion of fly ash and cement, values are further improved. The optimum percentage of mixture $20 \%$ fly ash and $8 \%$ cement gives the CBR value 10.12 , the best result for subgrade soil. Furthermore, by 

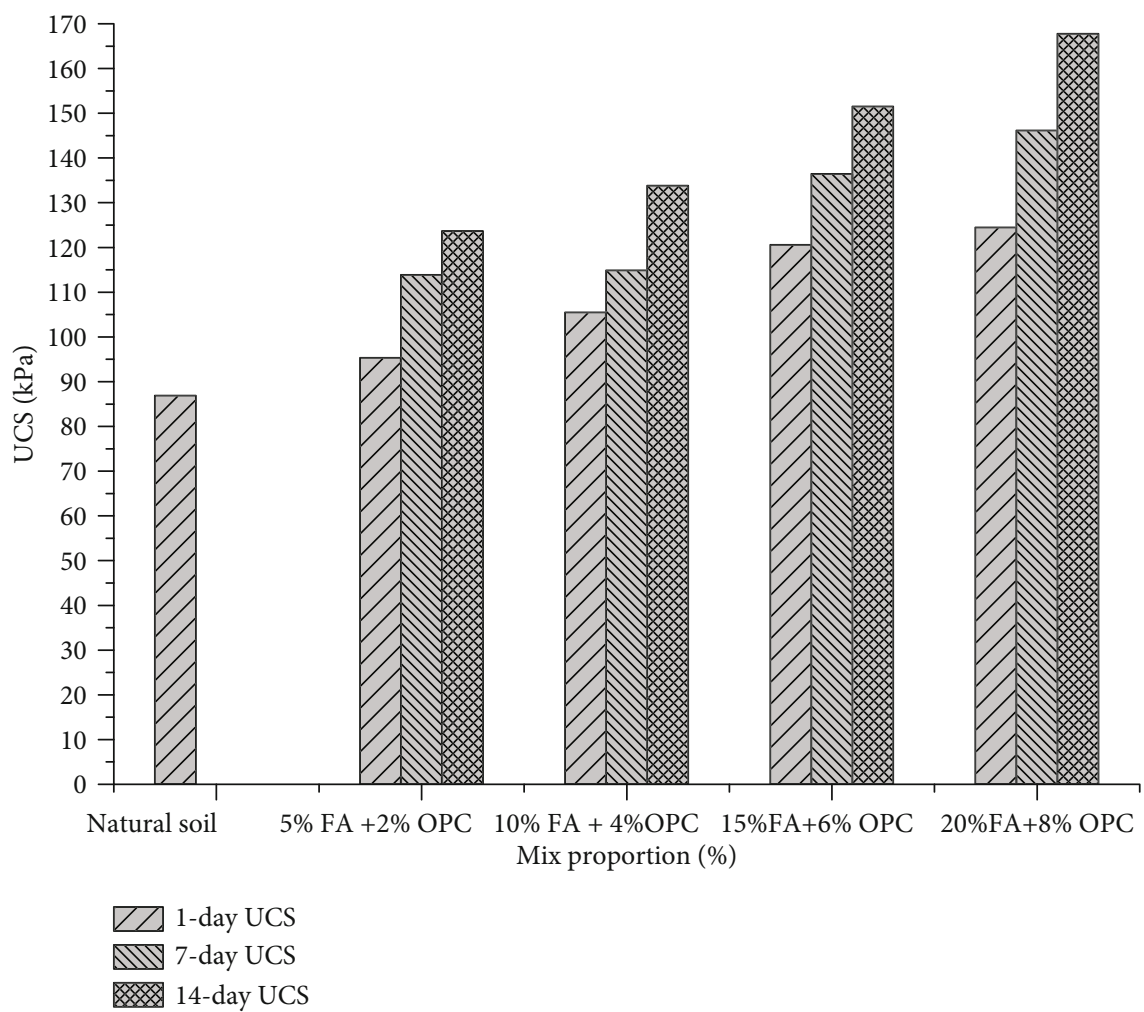

Figure 7: Comparison of unconfined compression strength for soil sample with, and without, fly ash and cement mixture.

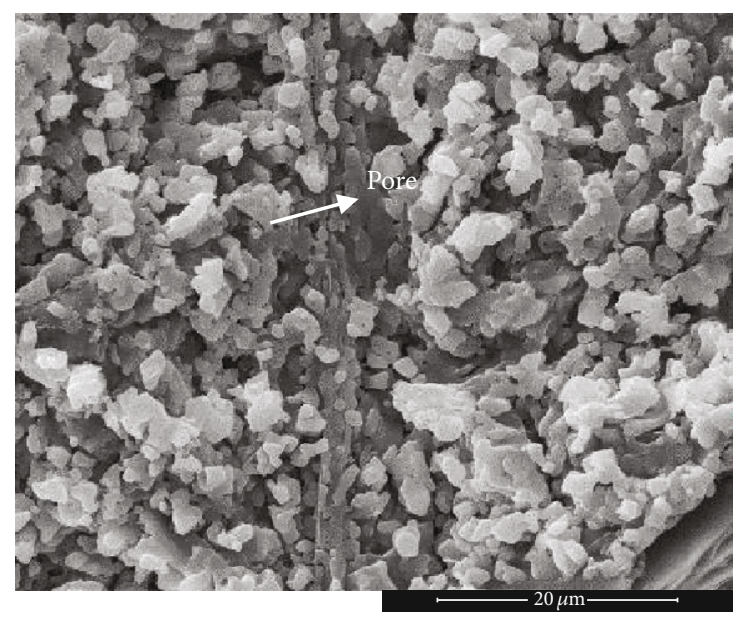

FIgURE 8: SEM image of natural soil.

performing dummy tests, the increase of the mixture supplement will lead to the decrease of CBR value from a dummy test, which indicates the reduction in subgrade strength.

\subsection{Influence by Fly Ash and Cement on Unconfined} Compressive Strength. Unconfined compressive strength test, referred to as an uniaxial compression test, is a special case of triaxial test. In the triaxial test, the unconfined pressure is zero. The application of the unconfined compression test (UCS) is to quickly estimate or evaluate the unconfined compressive strength of soil with enough cohesion to examine the unconfined state. Unlike fly ash and cement mix- tures, the unconfined compressive strength of subgrade soil is arranged in Table 6. This shows that the UCS value differs from the increase in the percentage of fly ash and cement used to calculate the shear strength.

The graph shown in Figure 7 illustrates the distinct compressive strength achieved in 1 days, 7 days, and 14 days by the subgrade soil with differing fly ash and cement proportions. There was a significant rise in soil strength after treatment comparison with natural soil, as shown in Figure 7. The results show that the unconfined compressive strength of undisturbed soil is $86.88 \mathrm{kPa}$ after one day of curing. Furthermore, the values were improved with the addition of additives. The 14-day test findings differ from the 1-day and 7-day test by demonstrating that the compressive strength improves with the inclusion of fly ash and cement. The changes of compressive strength up to a particular amount of different admixtures are required to fill the pores in the soil once the pores are filled, and the soil becomes densified. Further expansion may try to lose soil strength. The pozzolanic cementitious material produced by cement hydration reaction improves the bonding strength of soil particles [36]. The amount of pozzolanic cementitious material increases and hardens with the extension of curing time, which significantly enhances the compressive strength of treated soil. Besides, the maximum UCS value is inferred at $20 \%$ fly ash and $8 \%$ cement.

3.6. Influence of Fly Ash and Cement on Scanning Electron Microscopy Test (SEM). The micrographs of different scales were obtained to clarify the evaluation of microstructure. 


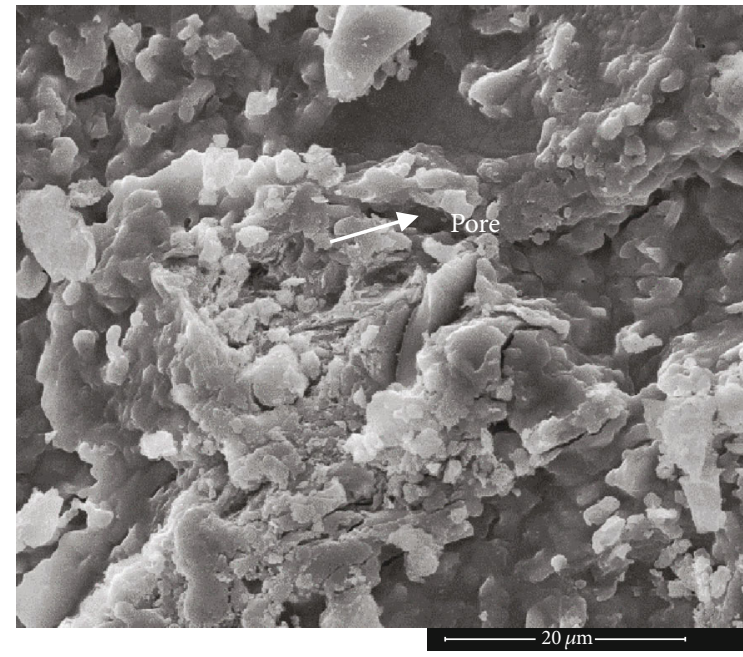

(a)

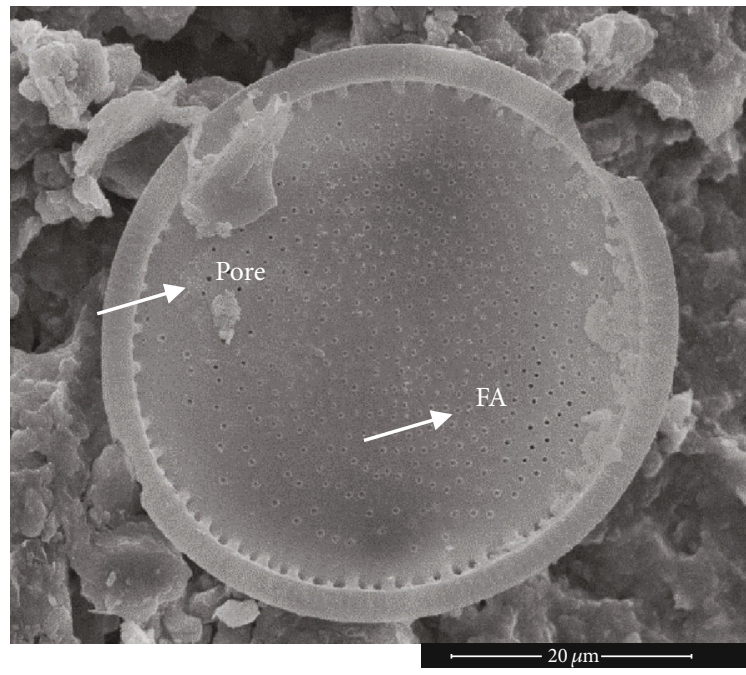

(c)

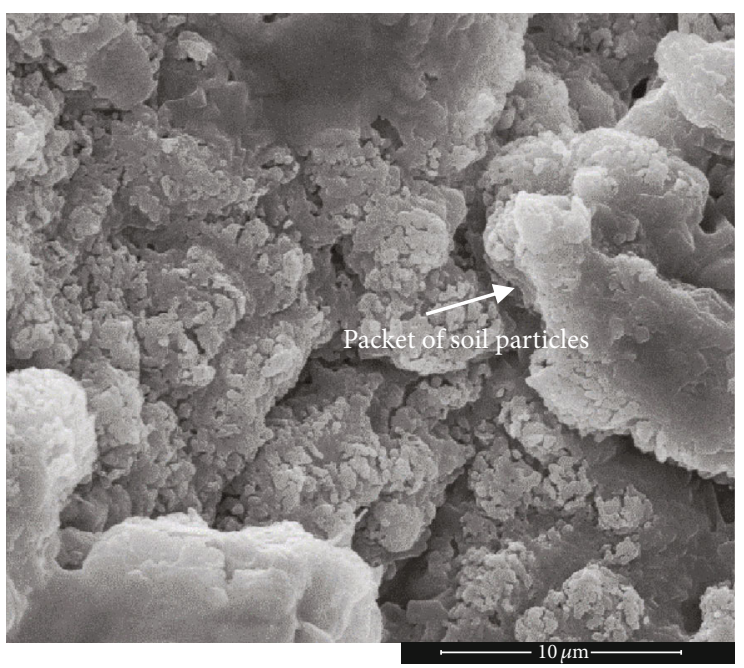

(b)

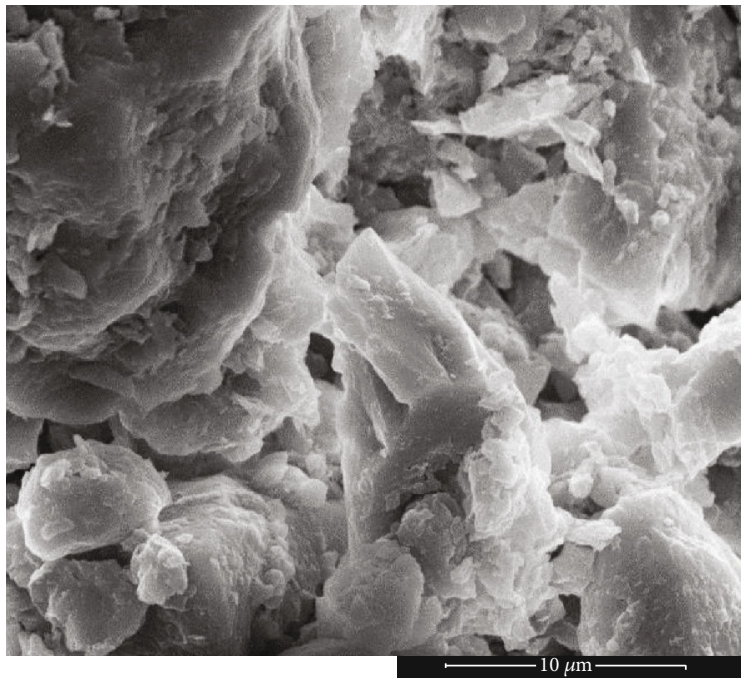

(d)

FIGURE 9: SEM photographs of treated soil containing varying percentages of fly ash and cement mixtures.

The scale of 20,10 $\mu \mathrm{m}$ was shown in Figures 8 and 9 for natural and treated soil. Figure 9 indicates that the apparent shape of the treated soil particles becomes coarser due to the bonding influence of fly ash and cement binder, where this binder served to attach the fine soil particles to each other, forming broader and larger clusters of photomicrographs.

Figures 9(a) and 9(b) show a closer SEM image of the treated soil. Compared with the untreated soil image Figure 8, new compounds can be identified in the microstructure of treated samples at (a) and (b). It indicates the formation of cementitious products of fly ash and cement.

Figures 9(c) and 9(d) show a micrograph of the soil mixed with bonded $15 \%$ fly ash and $6 \%$ cement. In this picture, undulating flake particles can be observed. However, the micrograph of the mixed soil shown in image (c) shows that the microstructure of the mixed soil is more dense, compacted, and coherent than that of the untreated soil shown in Figure 8. This confirms the development of cementitious products which are concerned with improving the geotechnical properties of treated soils in this investigation. The image in Figure 9(d) structure shows it. The results showed that the treated soil had fewer pores and highly denser.

\section{Conclusions}

The study highlighted the stabilization of the problematic subgrade soil with cement and fly ash was investigated, and the effect of the stabilization on the characteristics and geotechnical properties of the subgrade soil were studied. According to the experimental results, the following conclusions can be drawn:

(1) The plastic limit, liquid limit, and plasticity index of the subgrade soil increase first and then decrease with FA and cement content. Meanwhile, the swelling potential of soil also reduces with the inclusion of fly ash and cement. The swelling characteristic, namely, the free swelling index, decreased from 
$41 \%$ to $12 \%$, which is $70.73 \%$ lower than the initial value

(2) With the expansion of fly ash and cement content, the optimum moisture content decreases, and the maximum dry bulk density increases. The compaction curve drifts up and to the left as the optimal moisture content is reduced, and the maximum dry unit weight increased with an increase in fly ash and cement content. Adding fly ash and cement can be comparable with the improved compaction effect. Therefore, the subgrade soil becomes more stable

(3) With the increase of fly ash and cement content, the CBR value of soil increases. The CBR value of untreated soil was only 2.9; nevertheless, with the addition of fly ash and cement, the CBR value further increased. The optimum percentage of the mixture $(20 \%$ fly ash $+8 \%$ cement) gives the CBR value 10.12 , the best result for subgrade soil

(4) Significant increments were observed in the unconfined compressive strength $\left(q_{u}\right)$ of the treated soil. UCS increased with a steady increase in the proportion of fly ash and cement binder and age expansion. UCS of untreated soil is $86.88 \mathrm{kPa}$ after a one-day curing period. However, the maximum UCS of $167.75 \mathrm{kPa}$, i.e., $20 \% \mathrm{FA}+8 \%$ cement, increases to the initial value by $48.20 \%$.

(5) The results show that the microstructure of treated soil samples changes significantly after adding different amounts of fly ash and cement through the understanding of microscopic images. Firstly, the particle size of the natural soil seemed to be larger voids than that of the treated soil. After the additives, a cement gel identical to the structure was observed for fly ash and cement, which covered and bound soil particles to each other. A coherent and compacted soil structure was achieved because of the reduction in the volume of the treated soil

Based on the comprehensive analysis results, it can be concluded that wastes (by-products) such as fly ash and cement can be effectively used in civil engineering construction. Succinctly, due to the large amount of fly ash in Pakistan and the rest of the world, it would be beneficial to utilize large amounts of fly ash. Meanwhile, the use of stabilized soil in this method has the dual advantages of removal removing harmful substances from the environment and, at the same time, the usage of inexpensive construction material for foundations and road networks.

\section{Data Availability}

All data generated or analyzed during this study are included in this published article.

\section{Conflicts of Interest}

The authors declare that they have no conflict of interest.

\section{Acknowledgments}

The authors acknowledge and appreciate the technical support provided by the Mehran University of Engineering and Technology, Jamshoro, Sindh, Pakistan. This research was supported by the "National Natural Science Foundation of China (71942006)" and "Big Data-Driven Structural Disasters Prediction and Maintenance in Hazardous Geological Regions of Subsea Tunnels Grant No. 51991395)”.

\section{References}

[1] C. C. Ikeagwuani and D. C. Nwonu, "Emerging trends in expansive soil stabilisation: a review," Journal of Rock Mechanics and Geotechnical Engineering, vol. 11, no. 2, pp. 423-440, 2019.

[2] A. A. Firoozi, C. Guney Olgun, A. A. Firoozi, and M. S. Baghini, "Fundamentals of soil stabilization," International Journal of Geo-Engineering, vol. 8, no. 1, p. 26, 2017.

[3] D. Zhang, A. Ding, T. Li, and X. Wu, "Effects of passivators on Artemisia selengensis yield and Cd stabilization in a contaminated soil," Polish Journal of Environmental Studies, vol. 30, no. 2, pp. 1903-1912, 2021.

[4] D. Castro-Fresno, D. Movilla-Quesada, Á. Vega-Zamanillo, and M. A. Calzada-Pérez, "Lime stabilization of bentonite sludge from tunnel boring," Applied Clay Science, vol. 51, no. 3, pp. 250-257, 2011.

[5] C. McDowell, Stabilization of Soils with Lime, Lime-Flyash, and Other Lime Reactive Materials, Highw. Res. Board Bull., 1959, http://onlinepubs.trb.org/Onlinepubs/hrbbulletin/231/ 231-004.pdf.

[6] P. Indiramma, C. Sudharani, and S. Needhidasan, "Utilization of fly ash and lime to stabilize the expansive soil and to sustain pollution free environment - an experimental study," Materials Today: Proceedings, vol. 22, pp. 694-700, 2020.

[7] T. S. Nagaraj and N. Miura, "Soft clay behaviour : analysis and assessment," Brookfield, VT, Rotterdam, 2001, https://www .crcnetbase.com/isbn/9780415889285.

[8] S. D. Khadka, P. W. Jayawickrama, S. Senadheera, and B. Segvic, "Stabilization of highly expansive soils containing sulfate using metakaolin and fly ash based geopolymer modified with lime and gypsum," Transportation Geotechnics, vol. 23, article ???, 2020.

[9] A. E. Ramaji, "A review on the soil stabilization using low-cost methods," Journal of Applied Sciences Research, vol. 8, no. 4, pp. 2193-2196, 2012.

[10] B. R. Phanikumar and T. V. Nagaraju, "Effect of fly ash and rice husk ash on index and engineering properties of expansive clays," Geotechnical and Geological Engineering, vol. 36, no. 6, pp. 3425-3436, 2018.

[11] M. Abu-Farsakh, S. Dhakal, and Q. Chen, "Laboratory characterization of cementitiously treated/stabilized very weak subgrade soil under cyclic loading," Soils and Foundations, vol. 55, no. 3, pp. 504-516, 2015.

[12] D. K. Swain, S. K. Rautaray, and B. C. Ghosh, "Alkaline coal fly ash amendments are recommended for improving rice-peanut crops," Acta Agriculturae Scandinavica, Section B - Plant Soil Science, vol. 57, no. 3, pp. 201-211, 2007.

[13] C. Marieta, A. Guerrero, and I. Leon, "Municipal solid waste incineration fly ash to produce eco-friendly binders for 
sustainable building construction," Waste Management, vol. 120, pp. 114-124, 2021.

[14] B. J. Priatmadi, A. R. Saidy, and M. Septiana, "Soil properties and growth performance of rize (Oryza sativa L.) grown in a fly-ash amended soil," Tropical Wetland Journal, vol. 1, no. 1, pp. 19-24, 2015.

[15] H. Verma and A. Dubey, "The impact of fly ash application on the carbohydrate content of wheat (Triticum aestivum)," Journal of Agroecology and Natural Resource Management, vol. 6, no. 1, pp. 9-12, 2019.

[16] J. J. Camberato, E. D. Vance, and A. V. Someshwar, Composition and land application of paper manufacturing residuals, ACS Publications, 1997.

[17] R. C. Joshi and R. P. Lohita, Fly Ash in Concrete: Production, Properties and Uses, Taylor \& Francis, 1997.

[18] M. Singh and R. Siddique, "Effect of coal bottom ash as partial replacement of sand on workability and strength properties of concrete," Journal of Cleaner Production, vol. 112, pp. 620630, 2016.

[19] A. B. Mukherjee, R. Zevenhoven, P. Bhattacharya, K. S. Sajwan, and R. Kikuchi, "Mercury flow via coal and coal utilization by-products: a global perspective," Resources, Conservation and Recycling, vol. 52, no. 4, pp. 571-591, 2008.

[20] V. C. Pandey and N. Singh, "Impact of fly ash incorporation in soil systems," Agriculture, Ecosystems and Environment, vol. 136, no. 1-2, pp. 16-27, 2010.

[21] Global Cement staff, "Diamer Basha Dam to use concrete containing fly ash - cement industry news from Global Cement," 2020, 2021, https://www.globalcement.com/news/item/ 11101-diamer-basha-dam-to-use-concrete-containing-flyash.

[22] M. J. Munir, S. M. S. Kazmi, Y.-F. Wu, and I. Patnaikuni, “A literature review on alkali silica reactivity of concrete," International Journal of Strategic Engineering, vol. 1, no. 2, pp. 43-62, 2018.

[23] B. R. Phani Kumar and R. S. Sharma, "Effect of fly ash on engineering properties of expansive soils," Journal of Geotechnical and Geoenvironmental Engineering, vol. 130, no. 7, pp. 764$767,2004$.

[24] G. Albayrak and U. Albayrak, "Civil Engineering Journal," Civil Engineering, vol. 2, no. 10, 2016.

[25] EuroSoilStab, "Design guide: soft soil stabilisation. EuroSoilStab: development of design and construction methods to stabilise soft organic soils," 2002, http://BREbookshop.com.

[26] X. Zhang, W. Li, Z. Tang, X. Wang, and D. Sheng, "Sustainable regenerated binding materials (RBM) utilizing industrial solid wastes for soil and aggregate stabilization," Journal of Cleaner Production, vol. 275, p. 122991, 2020.

[27] C. C. Ikeagwuani, I. N. Obeta, and J. C. Agunwamba, "Stabilization of black cotton soil subgrade using sawdust ash and lime," Soils and Foundations, vol. 59, no. 1, pp. 162-175, 2019.

[28] P. Rai, H. Pei, F. Meng, and M. Ahmad, "Utilization of marble powder and magnesium phosphate cement for improving the engineering characteristics of soil," International Journal of Geosynthetics and Ground Engineering, vol. 6, no. 2, p. ???, 2020.

[29] U Joint Departments of the Army and the Air Force, "Soil stabilization for pavements," in Tech. Man. No. 5-822-14; Air Force Man. No. 32-1019, pp. 2-57, University Press of the Pacific, 2004.
[30] J. Muthuramalingam and L. Sing, "Experimental studies on treated sub-base soil with fly ash and cement for sustainable design recommendations," International Journal of Engineering and Applied Sciences, vol. 6, no. 8, pp. 331-334, 2012.

[31] C. Fan, B. Wang, and T. Zhang, "Review on cement stabilization/solidification of municipal solid waste incineration fly ash," Advances in Materials Science and Engineering, vol. 2018, Article ID 5120649, 7 pages, 2018.

[32] Q. Tang, Y. Liu, F. Gu, and T. Zhou, "Solidification/stabilization of fly ash from a municipal solid waste incineration facility using Portland cement," Advances in Materials Science and Engineering, vol. 2016, Article ID 7101243, 10 pages, 2016.

[33] P. Venkara Muthyalu, K. Ramu, and G. V. R. Prasada Raju, "Study on performance of chemically stabilized expansive soil," International Journal of Advances in Engineering and Technology, vol. 2, no. 1, pp. 139-148, 2012.

[34] P. Ganapati Naidu, P. V. V. Satyanarayana, C. Sekar Ganja, and K. Durga Rani, "Effect of cement on cement stabilized low plastic graded gravel soils," Materials Today: Proceedings, 2021.

[35] N. K. Sharma, S. K. Swain, and U. C. Sahoo, "Stabilization of a clayey soil with fly ash and lime: a micro level investigation," Geotechnical and Geological Engineering, vol. 30, no. 5, pp. 1197-1205, 2012.

[36] E. O. Tastan, T. B. Edil, C. H. Benson, and A. H. Aydilek, "Stabilization of organic soils with fly ash," Journal of Geotechnical and Geoenvironmental Engineering, vol. 137, no. 9, pp. 819833, 2011.

[37] W. G. Holtz, "Engineering properties of expansive clays," Transactions of the American Society of Civil Engineers, vol. 121, pp. 641-677, 1954. 